Short Report

\title{
Synthesis of $N$-Phtaloyl Amino Acid p-tert-butylcalix[4]arene Esters
}

\author{
Márcio Lazzarotto $^{a^{*}}$, Francine Furtado Nachtigall ${ }^{a}$ and Faruk Nome ${ }^{b}$ \\ ${ }^{\mathrm{a}}$ Departamento de Química, Universidade Estadual de Ponta Grossa, \\ Praça Santos Andrade, s/n, 84030-000, Ponta Grossa - PR, Brazil \\ ${ }^{\mathrm{b}}$ Departamento de Química, Universidade Federal de Santa Catarina, \\ Campus Universitário, 88040-900, Florianópolis - SC, Brazil
}

\begin{abstract}
Ésteres de $N$-ftaloil amino ácidos e p-terc-butilcalix[4]areno foram sintetizados, e somente os produtos bis-substituídos em conformação 1,3 alternada foram isolados. Os ésteres de aminoácidos quirais sofreram racemização completa ou parcial no meio reacional $\left(\mathrm{Et}_{3} \mathrm{~N} / \mathrm{CH}_{2} \mathrm{Cl}_{2}\right)$.

1-3-Diesters of $p$-tert-butylcalix[4]arene were obtained upon reaction with $N$-phtaloyl amino acid chlorides. Reactions with chiral amino acids were accompanied by complete or partial racemization in the reaction media $\left(\mathrm{Et}_{3} \mathrm{~N} / \mathrm{CH}_{2} \mathrm{Cl}_{2}\right)$.
\end{abstract}

Keywords: calixarenes, supramolecular chemistry, amino acid chlorides.

The chemistry of calixarenes has received increasing attention in the field of Supramolecular Chemistry, as this class of molecules offers a suitable platform for the synthesis of receptors for anions, cations and neutral molecules. Their structures allow acylation and alkylaton reactions of the phenolic groups.

The conformation and degree of substitution of acylated products are related to the reagent used to promote the reaction; the substituent at para position of the calixarene and the acid chloride. For example, Gutsche reported tetrasubstitution in the reaction of $p$-tert-butylcalix[4]arene with $p$-substituted benzoyl chlorides, using $\mathrm{AlCl}_{3}$ or $\mathrm{NaH}$ as catalyst. In this case the products had 1,3 alternate, partial cone and cone conformations ${ }^{4 \mathrm{a}}$ while when pyridine was used as catalyst, only trisubstituted calix[4]arene in partial cone was obtained ${ }^{6}$.

The complexation and transport of racemic mixtures with chiral receptors has been pointed out as a smooth method for enantiomeric resolution, because it requires low concentrations of the receptor, which can be recovered at the end of the process. Chiral receptors based on calix[4]arene structures are obtained by three approaches: reaction of calixarenes with chiral compounds ${ }^{7}$, use of four different phenols as building blocks for cyclization in the synthesis of calixarenes ${ }^{8}$, and from functionalization of achiral calixarenes on meta-positions of the aromatic rings, leading to an inherently chiral conformation ${ }^{9}$.

In this work, we report the synthesis of calixarene amino acid esters and their structures have been elucidated by ${ }^{1} \mathrm{H}$ NMR spectroscopy.

\section{Results and Discussion}

$N$-Phthaloyl amino acid calix[4]arene esters 1 - 6 were synthesized from $p$-tert-butylcalix[4]arene and the corresponding $\mathrm{N}$-Pht amino acid chlorides in the presence of $\mathrm{Et}_{3} \mathrm{~N}$, using a molar ratio of 10:10:1 of $\mathrm{Et}_{3} \mathrm{~N}$ : amino acid chloride: $p$-tert-butylcalix[4]arene, respectively. In the case of the glycine derivative, the reaction was also performed using $\mathrm{AlCl}_{3}$. In this reaction, a molar ratio of 70:10:1 of $\mathrm{AlCl}_{3}$ : amino acid chloride: $p$-tert-butyl-calix[4]arene was used and only non-reacted calixarene was recovered when a molar ratio of 20:10:1 was used. This lack of efficiency in lower $\mathrm{AlCl}_{3}$, amino acid chloride ratio is attributed to the Lewis acid characteristics of $\mathrm{AlCl}_{3}$, that would be inactivated by interaction with the lone pairs of $\mathrm{N}$-phtaloyl amino acid derivative.

Both methods yield bis substituted products on distal phenolic oxygens, and the product of tetra-substitution was not isolated, although a large excess of all reagents in relation to calixarene was used. The products adopt 1,3-alternate conformation, as two semi-calixes, an unusual pattern for bis-substituted calix[4]arenes, by the lack of intramolecular hydrogen bonds as additional stabilization forces. The yields of the reactions were $70-80 \%$, and the pure products were obtained after recrystallization from chloroform-methanol, with exception of Gly derivative $\mathbf{1}$ which was recrystallized from chloroform.

In the IR spectra, the $\mathrm{OH}$ stretching $\left(\mathrm{v}_{\mathrm{OH}}\right)$ appears as a narrow band above $3500 \mathrm{~cm}^{-1}$ for all aminoacid ester 


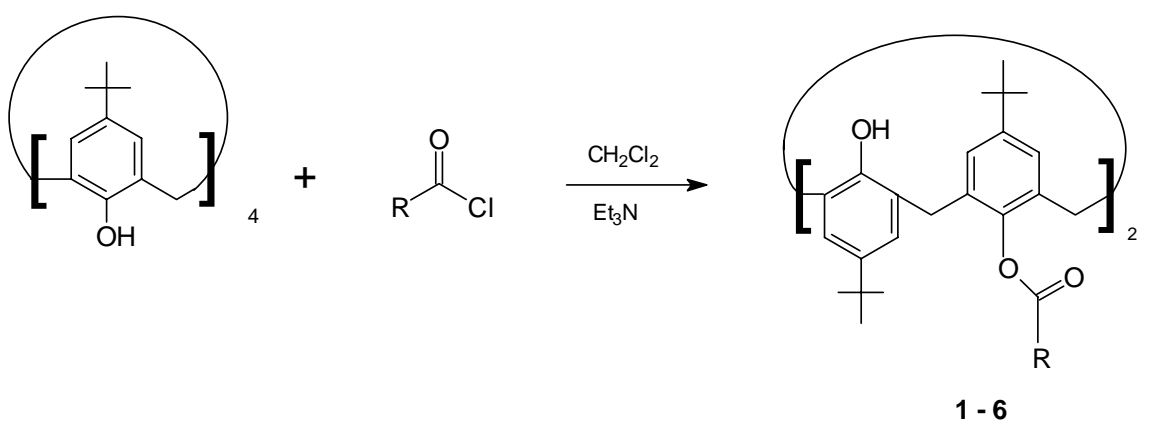

1, $\mathrm{R}=\mathrm{CH}_{2} \mathrm{NPht}$; 2, R= $\mathrm{CH}\left(\mathrm{CH}_{2} \mathrm{Ph}\right) \mathrm{NPht} ; 3, \mathrm{R}=\mathrm{CH}\left(\mathrm{CH}_{2} \mathrm{CH}\left(\mathrm{CH}_{3}\right)_{2}\right) \mathrm{NPht}$;

4, R= $\mathrm{CH}_{2} \mathrm{CH}_{2} \mathrm{NPht}$; 5, R= $\mathrm{CH}\left(\mathrm{CH}_{2} \mathrm{CH}_{2} \mathrm{CH}_{2} \mathrm{NPht}\right) \mathrm{NPht}$; 6, R= $\mathrm{CH}\left(\mathrm{CH}_{3}\right) \mathrm{NPht}$

Scheme 1: Synthesis of $p$-tert-butylcalix[4]arene- $N$-Pht-amino acid esters.

derivatives. The frequency depends on the aminoacid residue, and is higher for bulkier residues ( $N$-Pht-Phe 2, $N$-Pht-Leu 3; $\mathrm{v}_{\mathrm{OH}} 3550 \mathrm{~cm}^{-1}$ ). This is consistent with a 1,3 -alternate conformation, adopted by the calixarene, where the remaining phenolic hydrogens are placed at opposite sides in relation to the substituted oxygens. Consequently, intramolecular hydrogen bonds between $\mathrm{O}-\mathrm{H}$ and substituted oxygens are not possible. In the case of bis-substituted cone conformers, whose four oxygen atoms are located in suitable positions for intramolecular hydrogen bonds, a broadening of the bands and a decreasing of the frequency $\left(v_{\mathrm{OH}} 3200-\right.$ $3300 \mathrm{~cm}^{-1}$ ) is observed ${ }^{7 b}$.

The ${ }^{1} \mathrm{H}$ NMR of the $N$-Pht-Gly derivative 1 shows two tert-butyl signals with equal integrals at $\delta 1.11$ and 1.38 , attributed to the tert-butyl hydrogens of the phenolic and the ester residues, and two doublets that correspond to methylenic hydrogens at $\delta 3.65$ and 3.81 ; the difference of $\Delta \delta 0.16$ between both signals is typical of a 1,3 alternate conformer. This $\Delta \delta$ value can be used to assign the structure, where higher values $(\Delta \delta \sim 1.0)$ are obseved for the cone conformer (less symmetric conformer) and lower values for 1,3 alternate conformer (more symmetric conformer).

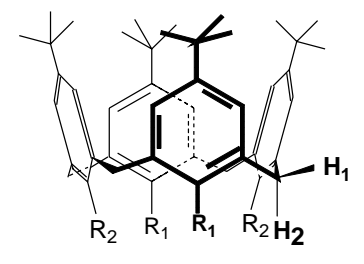

cone

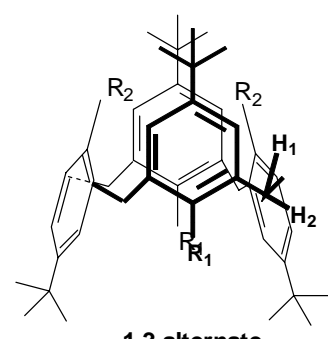

1,3 alternate
Figure 1: Cone and 1,3 alternate conformations of p-tert-butylcalix[4]arene derivatives

The ${ }^{1} \mathrm{H}$ NMR of the N-Pht- $\beta$-Ala- $p$-tert-butylcalix[4] arene 4 has the same ${ }^{1} \mathrm{H}$ NMR pattern, but the value of $\Delta \delta$ increases to 0.30 . Both methylenic hydrogens are more shielded than in the corresponding N-Pht-Gly derivative, with doublets centered at $\delta 3.40$ and 3.70 .

For chiral amino acid esters, the spectra are more complex for two reasons: diastereotopism of aromatic and methylenic hydrogens and racemization, with consequent formation of diastereoisomers. The diastereoisomeric excess was estimated by the difference in the integrals of the hydrogen signals for both diastereoisomers, and was found to be $72 \%$ for calixarene $N$-Pht-Phe 2, 50\% for $N$-Pht-Leu 3 and bis$\mathrm{N}$-Pht-Orn 5 derivatives and complete racemization for $\mathrm{N}$ Pht-Ala ester 6. The degree of racemization seems to be related to the volume of the side chain, that makes difficult the removal of the $\alpha$-hydrogen by the base.

The ${ }^{1} \mathrm{H}$ NMR of $\mathbf{6}$ shows three tert-butyl signals and eight doublets, corresponding to the methylene signals. Surprisingly, the phenolic hydrogen signals are affected by the chiral centers, and an integration ratio of 1:2:1 was observed. For the $(\mathrm{R}, \mathrm{R}) /(\mathrm{S}, \mathrm{S})$ pair, both phenolic hydrogens are magnetically equivalent, but the $(R, S) /(S$, R) pair presents two signals corresponding to phenolic hydrogens, which indicates that intra- or intermolecular hydrogen exchange does not occur in NMR time scale.
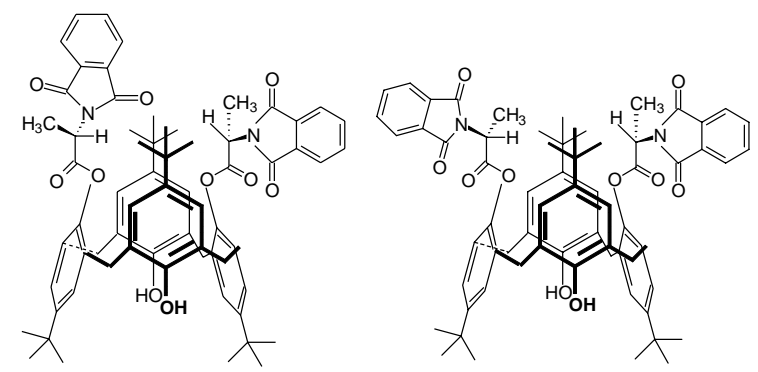

Figure 2: (a) (S,S)-diastereoisomer of 6; (b) (R,S)-diastereoisomer of 6

Noteworthy are the chemical shifts of tert-butyl protons. The $\delta$ values for tert-butyl hydrogens of substituted phenol rings, located on the same side of non-reacted $\mathrm{OHs}$ remain 
almost unchanged in the amino acid series $(\delta \sim 1.35)$, while for hydrogens of tert-butyl groups of unsubstituted rings, located in the same side of N-Pht amino acid, we observed a shift to higher field with the increase of the size of the side chain of the amino acid. The highest $\delta$ value corresponds to N-Pht-Gly derivative $1(\delta 1.11)$ and lowest for N-Pht-Leu $3(\delta 0.83)$. This indicates an increase in steric crowding between the side chain of the amino acid and the tert-butyl group of the unsubstituted phenolic unit. Consequently, there is a distortion of the structure that may also be detected by the difference in the values of NMR signals of the methylenic hydrogens $(\Delta \delta)$. Here, the lowest $\delta$ value corresponds to $N$-Pht-Gly derivative and the highest corresponding to $N$-Pht-Phe derivative. This feature is attributed to differences in the chemical environment between these hydrogens for branched amino acids, related with the proximity with phenolic oxygens.

The analysis of these data allows to conclude that the geometrical parameters of the cavity can be controlled by the linked amino acid, and this result in a a fine tuning of the opening of calixarene hollow.

In conclusion, bis-substituted calix[4]arenes amino acid esters with 1,3 alternate conformation were obtained, in contrast to the usual cone conformation of bis-substituted derivatives, which may be further functionalized by acylation or alkylation reactions of the remaining phenolic oxygens. As a sequence of this work, ditopic receptors will be synthesized by linkage of groups with metal complexational properties (e. $g$. crown ethers) .

\section{Acknowledgements}

This investigation was supported by PADCT, CNPq, PRONEX and CAPES.

\section{References}

1. For review articles on calixarenes see: (a) Böhmer, V. Angew Chem. 1995, 107, 785; (b) Ikeda, A.; Shinkai, S. Chem. Rev. 1997, 97, 1713; (c) Lazzarotto, M.; Nachtigall, F. F.; Nome, F. Quim. Nova 1995, $18,444$.

2. (a) Beer, P. D.; Shade, M. Gazz. Chim. Ital. 1997, 127, 1360; (b) Jasat, A.; Sherman, J. C. Chem. Rev. 1999, 99, 931 .

3. (a) Arnaud-Neu, F.; Collins, E. M.; Deasy, M.; Ferguson, G.; Harris, S. J.; Daitner, B.; Lough, A. J.; McKervey, M. A.; Marques, E.; Ruhl, B. L.; SchwingWeill, M. J.; Seward, E. M. J. Am. Chem. Soc. 1989, 111, 8681; (b) Van Wageningen, A. M. A.; Verboom, W.; Zhu, X.; Ripmeester, J. A.; Reinhoudt, D. N.
Supram. Chem. 1998, 9, 31; (c) Iwamoto, K.; Araki., K.; Shinkai, S. J. Org. Chem. 1991, 56, 4955.

4. (a) Iqbal, M.; Mangiafico, T.; Gutsche, C. D. Tetrahedron 1987, 43, 4917; (b) No, K. H.; Koo, H. J. Bull. Kor. Chem. Soc. 1994, 15, 483.

5. (a) Muthukrishnan, R.; Gutsche, C. D. J. Org. Chem. 1979, 44, 3962; (b) Atsushi, I.; Nagasaki, T.; Shinkai, S. J. Phys. Org. Chem. 1992, 5, 699; (c) Nagasaki, T.; Yusuke, T.; Shinkai, S. Recl. Trav. Chem. Pays-Bas. 1993, 112, 407; (d) Shinkai, S.; Arimura, R.; Kawabata, H.; Murakami, H.; Iwamoto, K J. Chem. Soc. Perkin Trans. 1 1991, 2429; (e) Sansone, F.; Barboso, S.; Casnati, A.; Fabbi, M.; Pochini, A.; Ugozzoli, F.; Ungaro, R. Eur. J. Org. Chem. 1998, 897.

6. Iqbal, M.; Mangiafico, T.; Gutsche, C. Tetrahedron 1987, 43, 4917.

7. Gutsche, C. D.; Lin, L. Tetrahedron 1986, 42, 1633.

8. (a) Böhmer, V.; Marschollek, F.; Zetta, L. J. Org. Chem. 1987, 52, 3200; (b) Lazzarotto, M.; Vencato, I.; Nachtigall, F. F.; Nome, F. J. Chem. Soc. Perkin Trans. 2 1998, 995.

9. Pappalardo, S.; Giunta, L.; Foti, M.; Ferguson, G.; Gallagher, J. F.; Kaitner, B. J. Org. Chem. 1992, 57, 2611.

10. Sheehan, J. C.; Frank, V. S. J. Am. Chem. Soc. 1949, 71,1856

11. Experimental data: The NMR analyses were performed in a Bruker spectrometer (200 and 50.3 $\mathrm{MHz}$ for hydrogen and carbon, respectively) using TMS as internal reference standard. IR analyses were performed in a FTIR-Bomem spectrophotometer as $\mathrm{KBr}$ pellets. The standard synthetic procedure is described below: $0.5 \mathrm{mmol}$ of freshly prepared the $N$-phtaloyl-aminoacid chloride, dissolved in $5 \mathrm{~cm}^{3}$ of $\mathrm{CH}_{2} \mathrm{Cl}_{2}$ was slowly added to a suspension of $0.5 \mathrm{mmol}$ of $p$-tert-butylcalix[4]arene, $0.5 \mathrm{~cm}^{3}$ of $\mathrm{Et}_{3} \mathrm{~N}$ and 5 $\mathrm{cm}^{3}$ of $\mathrm{CH}_{2} \mathrm{Cl}_{2}$ at $0^{\circ} \mathrm{C}$ during $15 \mathrm{~min}$. The suspension was kept at $0^{\circ} \mathrm{C}$ for 30 minutes and $24 \mathrm{~h}$ at room temperature. The solvent was removed under vacuum and methanol added to the reaction mixture, which was then filtered. The $N$-phtaloyl-aminoacid-p-tertbutylcalix[4]arene derivatives were re-crystallized from $\mathrm{CHCl}_{3} / \mathrm{MeOH}$ or $\mathrm{CHCl}_{3}$ The values of diastereoisomeric excess were calculated using the values of integrals for the $\mathrm{OH}$ signals of each diastereoisomer in the ${ }^{1} \mathrm{H}$ NMR spectra.

bis- $\boldsymbol{N}$-Pht-Gly-p-terc-butylcalix[4]arene (1): Yield: $0,461 \mathrm{~g}(89 \%) ; \mathrm{mp} 320^{\circ} \mathrm{C}$ (dec.); IR $v_{\max } / \mathrm{cm}^{-1} 3504$ (O-H, sharp), 2954 (C-H), 1765 (C=O), 1725 (C=O), $1180\left(\mathrm{CH}_{2}\right) ;{ }^{1} \mathrm{H}$ NMR $\left(200 \mathrm{MHz}, \mathrm{CDCl}_{3}\right) \delta 1.11$ 
(s, $18 \mathrm{H}, \mathrm{t}-\mathrm{Bu}) ; 1.37(\mathrm{~s}, 18 \mathrm{H}, t-B u) ; 3.65(\mathrm{~d}, J 14.8$ $\mathrm{Hz}, 4 \mathrm{H}, \mathrm{Ar}-\mathrm{CH}-\mathrm{Ar}$ ); 3.81 (d, J $14.8 \mathrm{~Hz}, 4 \mathrm{H}, \mathrm{Ar}-\mathrm{CH} .-$ $\mathrm{Ar}) ; 4.37$ (s, 4H, $\left.\mathrm{COCH}_{2}\right) ; 4.55$ (s, 2H, OH), 7.06 (s, 8H, CH Ar); 7.28 (s, 8H, CHAr); ${ }^{13} \mathrm{C}$ NMR (50.3 $\left.\mathrm{MHz}, \mathrm{CDCl}_{3}\right) \delta$ 31.14, $31.81\left(\mathrm{C}\left(\mathrm{CH}_{3}\right)_{3}\right) ; 34.12$ $\left(\mathrm{C}\left(\mathrm{CH}_{3}\right)_{3}\right) ; 35.38\left(\mathrm{Ar}-\mathrm{CH}_{2}\right) ; 38.63\left(\mathrm{CH}_{2} \mathrm{Gly}\right) ; 123.72$; $125.88 ; 126.74 ; 127.30 ; 132.08 ; 132.38 ; 134.33$; 142.61; 149.37; 150.69 (C Ar); 165.60, $167.46(\mathrm{C}=\mathrm{O})$; Elemental analysis- Found: C, 74.60; H, 6.62; N, 2.80: Calc. for $\mathrm{C}_{64} \mathrm{H}_{66} \mathrm{~N}_{2} \mathrm{O}_{10}+1 / 8 \mathrm{CHCl}_{3}$ : C, 74.20; $\mathrm{H}$, $6.63 ; \mathrm{N}, 2.63$.

bis- $N$-Pht-Phe-p-terc-butylcalix[4]arene (2): Yield: 0,440 g (72\%); mp $320{ }^{\circ} \mathrm{C}$ (dec.). IR $v_{\max } / \mathrm{cm}^{-1} 3558$, 2954, 1760, 1715, 1155. ${ }^{1} \mathrm{H}$ NMR (200 MHz, $\left.\mathrm{CDCl}_{3}\right)$ : $\delta 0.89\left(\mathrm{~s}, 18 \mathrm{H}, \mathrm{CH}_{3} \mathrm{t}-\mathrm{Bu}\right) ; 1.38\left(\mathrm{~s}, 18 \mathrm{H}, \mathrm{CH}_{3} t-\mathrm{Bu}\right) ;$ 3.33 (d, 2H, J 13.3, Ar-CH - -Ar.); 3.49 (d, 2H, J 14.3, Ar- $\mathrm{CH}_{2}$-Ar.); 3.83 (m, 4H, $\mathrm{CH}_{2}$ Phe); 4.01 (d, J 13.3 $\mathrm{Hz}, 2 \mathrm{H}, \mathrm{ArCH}_{2} \mathrm{Ar}$ ); 4.24 (d, J $14.3 \mathrm{~Hz}, 2 \mathrm{H}, \mathrm{ArCH}_{2} \mathrm{Ar}$ ); $5.08,5.30$ (s, 2H, OH); 5.46 (q, J $3.6 \mathrm{~Hz}, 2 \mathrm{H}, \mathrm{CH}$ Phe); 6.70 (d, J 2Hz, 2H, HAr); 6.72 (d, 2H, J 2, HAr); 6.90 (s, 10H, HAr-Phe); 7.17 (d, J 2Hz, 2H, HAr); 7.20 (d, J 2 Hz, 2H, HAr.); 7.60- 7.73 (8H, HAr-Pht, m). Diastereoisomeric excess: $72 \%$; Elemental analysisFound: C, 77.38; H, 6.57; N, 2.30. Calc. for $\mathrm{C}_{78} \mathrm{H}_{78} \mathrm{~N}_{2}$ $\mathrm{O}_{10}+1 / 8 \mathrm{CHCl}_{3}$ : C, 77.02; H, 6.46; N, 2.30.

bis- $\boldsymbol{N}$-Pht-Leu-p-terc-butylcalix[4]arene (3): Yield: $0,400 \mathrm{~g}(70 \%) \mathrm{mp}>320^{\circ} \mathrm{C}$. IR $v_{\max } / \mathrm{cm}^{-1} 3560,2955$, 1764, 1721, 1390. ${ }^{1} \mathrm{H}$ NMR (200 MHz, $\left.\mathrm{CDCl}_{3}\right): \delta 0.82$, $0.83(\mathrm{~s}, 18 \mathrm{H}, t-\mathrm{Bu}) ; 1.08\left(\mathrm{~m}, 12 \mathrm{H}, \mathrm{CH}_{3}\right) ; 1.29,1.35$, $1.36(\mathrm{~s}, 18 \mathrm{H}, t-\mathrm{Bu}) ; 2.45,2.75\left(\mathrm{~m}, 2 \mathrm{H}, \mathrm{CH}_{2}\right) ; 3.15-3.50$ (m, $\left.\mathrm{ArCH}_{2} \mathrm{Ar}, 4 \mathrm{H}\right)$ 3.65-4.15 (m, $\left.\mathrm{ArCH}_{2} \mathrm{Ar}, 4 \mathrm{H}\right)$; 4.98, 5.0 (s, 2H, OH); 5.48, 5.55 (dd, 2H, J 14.0 and $4.0 \mathrm{~Hz}$ CH Leu); 6.58 (s, 4H, CH Ar.); 7.11 (d, J 2Hz 4H, CH Ar); 7.73 (m, 4H, CHAr-Pht); 7.89 (m, 4H, CHAr-Pht); diastereoisomeric excess: $75 \%$. Elemental analysisFound: C, 75.31; H, 7.20; N, 2.47. Calc. for $\mathrm{C}_{72} \mathrm{H}_{82} \mathrm{~N}_{2} \mathrm{O}_{10}+1 / 8 \mathrm{CHCl}_{3}$ : C, 75.22, H 7.45, N 2.41. bis- $\boldsymbol{N}$-Pht- $\boldsymbol{\beta}$-Ala-p-terc-butylcalix[4]arene (4): Yield: $0,420 \mathrm{~g}(78 \%) \mathrm{mp} 256{ }^{\circ} \mathrm{C}$. IR $v_{\max } / \mathrm{cm}^{-1} 3553,2954$, 1760, 1715, 1155; ${ }^{1} \mathrm{H}$ NMR (200 MHz, $\left.\mathrm{CDCl}_{3}\right): \delta 0.93$ $(\mathrm{s}, 18 \mathrm{H}, t-\mathrm{Bu}) ; 1.30(\mathrm{~s}, 18 \mathrm{H}, t-\mathrm{Bu}) ; 3.19(\mathrm{t}, J 4.5 \mathrm{~Hz}, 4 \mathrm{H}$, $\left.\mathrm{CH}_{2}-\mathrm{N}\right) ; 3.40$ (d, J $\left.14.0 \mathrm{~Hz}, 4 \mathrm{H}, \mathrm{Ar}-\mathrm{CH}_{2}-\mathrm{Ar}\right) ; 3.70$ (d, $J$ $\left.14.0 \mathrm{~Hz}, 4 \mathrm{H}, \mathrm{Ar}-\mathrm{CH}_{2}-\mathrm{Ar}\right) ; 4.22$ (s, 4H, $\left.\mathrm{COCH}_{2}\right) ; 5.10$ (s, 2H, OH); 7.04 (s, 8H, CHAr); 7.62 (m, 4H, CHAr$\mathrm{Pht}) ; 7.75$ (m, 4H, CHAr-Pht); Elemental analysisFound: C, 73.55; H, 6.50; N3.00. Calc. for $\mathrm{C}_{66} \mathrm{H}_{70} \mathrm{~N}_{2}$ $\mathrm{O}_{10}+1 / 4 \mathrm{CHCl}_{3}: \mathrm{C}, 73.60 ; \mathrm{H} 6.55 ; \mathrm{N}, 2.60$.

bis- $N$-Pht-Orn-p-terc-butylcalix[4]arene (5): Yield: $0,490 \mathrm{~g}(70 \%) \mathrm{mp}>320^{\circ} \mathrm{C}$. IR $v_{\max } / \mathrm{cm}^{-1} 3560,2957$, 1765, 1716, 1388, ${ }^{1} \mathrm{H}$ NMR (200 $\left.\mathrm{MHz}, \mathrm{CDCl}_{3}\right): \delta$ 0.79 and $0.80 *(\mathrm{~s}, 18 \mathrm{H}, t-\mathrm{Bu}) ; 1.29,1.37(\mathrm{~s}, t-\mathrm{Bu})$; 1.9-2.1 (m, 4H, $\left.\mathrm{CH}_{2} \beta\right)$; 2.58 (q, J 7.5 Hz, 4H, $\mathrm{CH}_{2} \alpha$ ); 3.2-3.4 (m, 4H, $\left.\mathrm{ArCH}_{2} \mathrm{Ar}\right)$; 3.7-4.0 (m, 4H, $\mathrm{ArCH}_{2} \mathrm{Ar}$ ); 3.8 - 4.1 (m, 4H, $\left.\mathrm{CH}_{2} \gamma\right)$; 4.64, 4.73, 4.97 (s, 2H, OH); 5.68 (m, CH, 2H); 6.50, 6.55, 6.62 (d, J 2 Hz, CHAr, 2H); 6.90, 7.07, 7.10 (d, J 2 Hz, CHAr, 2H); 7.47 , 7.53 (d, J 2 Hz, CHAr, 2H); 7.68- 7.77 (m, 4 H, CHArPht); 7.85-7.95 (m, 4 H, CH-Pht); diastereoisomeric excess: 50\%. Elemental analysis-Found: $\mathrm{C}, 73.01 ; \mathrm{H}$, 6.05 ; N, 3.94. Calc. for $\mathrm{C}_{90} \mathrm{H}_{88} \mathrm{~N}_{4} \mathrm{O}_{10}+1 / 8 \mathrm{CHCl}_{3}$ : C, 72.96; H, 6.09; N, 3.78.

bis- $\boldsymbol{N}$-Pht-Ala-p-terc-butylcalix[4]arene (6): Yield: $0,400 \mathrm{~g}(75 \%) ; \mathrm{mp}>350{ }^{\circ} \mathrm{C}$ (dec.) ; IR $v_{\max } / \mathrm{cm}^{-1} 3509$ (O-H, sharp), 2954 (C-H), 1760,1725; ${ }^{1} \mathrm{H}$ NMR (200 $\mathrm{MHz}, \mathrm{CDCl}_{3}$ ): $\delta 0.97(\mathrm{~s}, 18 \mathrm{H}, t-\mathrm{Bu}) ; 1.35,1.34$, $1.44(\mathrm{~s}, 18 \mathrm{H}, t-\mathrm{Bu}) ; 1.81,1.85\left(\mathrm{~d}, J 2.7 \mathrm{~Hz}, 6 \mathrm{H}, \mathrm{CH}_{3}\right)$; 3.42-3.60 (m, 4H, Ar-CH-Ar); 3.75- 4.12 (m, 4H, Ar$\mathrm{CH}-\mathrm{Ar})$; 4.52, 4.87*, 5.09 (s, 2H, OH); 6.83-6.92 (d, J 2Hz, CHAr, 4H); 7.12-7.22 (d, J 2 Hz, CHAr, 4H,); 7.70-7.74 (m, 4H, CH-Pht); 7.85-7.89(m, 4H, CHArPht). Elemental analysis- Found: C, 74.74; H, 6.80; $\mathrm{N}$, 2.63. Calc. for $\mathrm{C}_{66} \mathrm{H}_{70} \mathrm{O}_{10} \mathrm{~N}_{2}+1 / 8 \mathrm{CHCl}_{3}$ : C, 74.49; H, 6.63; N, 2.63. *Signals are listed without assignment to a specific diastereoisomeric pair.

Received: April 15, 1999 Published on the web: April 2, 2001 